\title{
TECHNIQUE FOR ORDER PREFERENCE BY SIMILARITY TO IDEAL SOLUTION UNTUK MEMILIH JURUSAN BAGI SISWA SMA BERDASARKAN KECERDASAN GANDA
}

\author{
Moh. Ahsan ${ }^{1)}$, Devi Permatasari ${ }^{2)}$, Retno Marsitin ${ }^{3)}$ \\ 1) Teknik Informatika Universitas Kanjuruhan Malang \\ ${ }^{2)}$ Bimbingan Konseling Universitas Kanjuruhan Malang \\ ${ }^{3)}$ Pendidikan Matematika Universitas Kanjuruhan Malang \\ email:ahsan@unikama.ac.id ${ }^{l)}$,pevipermatasari@unikama.ac.id ${ }^{2}$, mars_retno@unikama.ac.id ${ }^{3)}$,
}

\begin{abstract}
Abstraksi
Setiap manusia mempunyai lebih dari satu kecerdasan ganda, seperti logika-matematika, visual-spasial, interpersonal, intrapersonal, linguistik, musikal, naturalis, dan kinestestis (Howard Gardner dari Harvard University). Banyak cara, untuk melihat kecerdasan seseorang diantaranya melalui angka, musik, gambar, katakata, kegiatan fisik atau sosial-emosional. Banyak hasil riset mengenai kecerdasan siswa, mengharap kepada orang tua dan wali murid agar selalu memberikan banyak pengaraha, stimulasi dan pengalaman kepada siswa.

Pendidikan menjadi point penting untuk orang tua dalam meningkatkan kecerdasan anaknya, dimana dalam lembaga pendidikan anak sebagai peserta didik atau siswa dapat diarahkan kepada bakat, minat dan potensi yang dimilikinya. Jika anak tidak tersentuh oleh dunia pendidikan maka potensi kecerdasan yang dimiliki seorang anak tidak akan berkembang dengan maksimal.

Pemilihan jurusan sejak awal bisa mempermudah siswa dalam memilih bidang ilmu atau jurusan yang akan ditekuninya di akademik, sekolah tinggi atau di Universitas kelak yang tentunya akan mengarah kepada masa depan dan karirnya. Sejak diberlakukannya kurikulum 2013 dimana sistem peminatan sudah dimulai dan dilakukan dari kelas Sepuluh atau kelas satu. Hal ini tentunya membutuhkan peran guru Bimbingan Konseling (BK) untuk mengarahkan anak ke bakat, minat dan potensi akademiknya. Pilihan tersebut terdiri dari Ilmu Pengetahuan Alam (IPA), Ilmu Pengetahuan Sosial (IPS), dan BAHASA (KEMEDIKBUD 2012).

Technique for Order Preference by Similiarty to Ideal Solution (TOPSIS) adalah diantara salah satu metode yang didalam MADM (Multiple-Attribute Decesion Making) dan merupakan salah satu pemodelan decision support system (SPK) digunakan untuk pengambilan sebuah keputusan dalam menetapkan kriteria yang terbaik dari beberapa alternatif berdasarkan beberapa kriteria yang telah ditentukan sebelumnya.
\end{abstract}

\section{Kata Kunci :}

Kecerdasan; Pendidikan; TOPSIS

Abstract
Everyone has more than one intelligence, including eight intelligences, linguistics, logic-mathematics, interpersonal, intrapersonal, musical, naturalist, visual-spatial, and kinestestic (Howard Gardner of Harvard University). Children's intelligence can be demonstrated in many ways, whether through words, numbers, music, pictures, physical activities (motor skills) or through social-emotional ways. A lot of research results on students 'intelligence, suggesting students' guardians to provide a lot of experience and stimulation to students.

Education is an important point for parents in improving the intelligence of their children, where in child education institutions as students or students can be directed to their talents, interests and potential. If the child is not touched by the world of education, the intelligence potential of a child will not develop optimally.

The direction of the department from an early age can make it easier for students to choose a field of knowledge that they will pursue in academic or university later which will also lead to his future career. Since the enactment of the 2013 curriculum where the specialization system has been started and done from class X. This certainly requires the role of the teacher of Guidance Counseling $(B K)$ to direct children to their talents, interests and academic potential. The choice consists of Natural Sciences (IPA), Social Sciences (IPS), and LANGUAGES (KEMEDIKBUD 2012).

Technique for Order Preference by Similiarty to Ideal Solution (TOPSIS) is one of the methods in MADM (Multiple Attribute Decesion Making) and is one of the decision support system (SPK) modeling that can be used in decision making to determine the best criteria from a number of alternatives based on certain criteria.

Keywords :

Intelligence; Education; TOPSIS 


\section{Pendahuluan}

Setiap orang mempunyai lebih dari satu kecerdasan, antara lain kecerdasan linguistik, logikamatematika, interpersonal, intrapersonal, musikal, naturalis, visual-spasial, dan kinestestis (Howard Gardner dari Harvard University). Kecerdasan seseorang atau anak bisa ketahui dengan banyak cara, diantaranya melalui angka, gambar, kata-kata, musik, kegiatan fisik dan sosial-emosional. Banyak hasil penelitian terkait dengan kecerdasan siswa, menyarankan para wali murid untuk memberi pengetahuan, pengalaman dan stimulasi kepada anak didiknya (siswa). Pemberian pengarahan, pengetahuan dan sensasi pengalaman yang sering dapat berguna untuk menumbuhkan dan membangkitkan kecerdasan anak yang dikristalkan ke dalam konsep teori kecerdasan yang disebutnya Kecerdasan Ganda (Adi W, 2006).

Pendidikan menjadi point penting untuk orang tua dalam meningkatkan kecerdasan anaknya, dimana dalam lembaga pendidikan anak sebagai peserta didik atau siswa dapat diarahkan kepada bakat, minat dan potensi yang dimilikinya. Jika anak tidak tersentuh oleh dunia pendidikan maka potensi kecerdasan yang dimiliki seorang anak tidak akan berkembang dengan maksimal. Peserta didik (siswa) Sebagai suatu komponen pendidikan, siswa dapat ditinjau dari berbagai pendekatan, antara lain: sosial, psikologis, dan edukatif/pedagogis (Hamalik, 2001).

Pengarahan jurusan sejak dini dapat memudahkan siswa memilih bidang ilmu yang akan ditekuninya di akademik atau universitas nantinya yang tentunya akan mengarah pula kepada karirnya kelak. Sejak berlakunya kurikulum 2013 dimana sistem peminatan sudah dimulai dan dilakukan dari kelas X. Hal ini tentunya membutuhkan peran guru Bimbingan Konseling (BK) untuk mengarahkan anak ke bakat, minat dan potensi akademiknya. Pilihan tersebut terdiri dari Ilmu Pengetahuan Alam (IPA), Ilmu Pengetahuan Sosial (IPS), dan BAHASA (KEMEDIKBUD 2012).

Mengingat pentingnya memetakan masa depan anak didik dengan tepat, maka penelitian ini mengambil obyek jurusan di SMA yang sesuai dengan bakat, minat dan potensi akademik siswa. Fokus penelitian ini adalah pada penentuan jurusan untuk Sekolah Menengah Atas (SMA) yang ditempuh dalam waktu tiga tahun, mulai dari kelas sepuluh (X) sampai kelas duabelas (XII). Kebanyakan siswa yang sudah lulus dari Sekolah Menengah Pertama (SMP) masih bingung dalam menentukan jurusan di Sekolah Tingkat Atas (SMA) bahkan masih ikut temannya dan tidak tahu kemampuan apa yang dimiliki pada dirinya sehingga jurusan yang diambil tidak sesuai dengan kemampuan dan potensinya.

Technique for Order Preference by Similiarty to Ideal Solution (TOPSIS) adalah diantara salah satu metode yang didalam MADM (MultipleAttribute Decesion Making) dan merupakan salah satu pemodelan decision support system (SPK) yang dapat digunakan dalam pengambilan keputusan untuk menetapkan kriteria terbaik dari sejumlah alternatif berdasarkan beberapa kriteria tertentu. Menurut Zimmermann, (1991) Multi Attribute Decision Making (MADM) digunakan untuk menyelesaikan masalah-masalah dalam ruang diskrit.

Mengingat latar belakang diatas dirasa perlu untuk melakukan penelitian dan pengembangan maka perlu sebuah decision support system dalam memilih jurusan di SMA berdasarkan kecerdasan ganda menggunkan menggunakan metode Technique for Order Preference by Similiarty to Ideal Solution. Sistem ini akan membantu siswa, orang tua, guru dan lembaga pendidikan sebagai pendukung untuk mengetahui jurusan di Sekolah Menengah Atas (SMA) yang sesuai dengan kecerdasan yang dimiliki.

\section{Tinjauan Pustaka}

\section{a. Multiple Criteria Decision Making (MCDM)}

Multiple Criteria Decision Making (MCDM) merupakan sebuah metode dalam pengambilan keputusan yang menetapkan alternatif yang terbaik dari beberapa kriteria yang telah ditentukan. Kriteria tersebut berupa parameter, ukuran-ukuran, aturanaturan atau hal-hal yang standar dan digunakan dalam pengambilan sebuah keputusan. MCDM tediri dari 2 model yaitu: 1). Multiple Attribute Decision Making (MADM) dan 2). Multiple Objective Decision Making (MODM). MADM dan MODM sering digunakan dalam menentukan atau menerangkan kelas atau katagori yang sama untuk pilihan yang terbaik. Sedangkan MADM digunakan dalam menyelesaikan masalah yang berhubungan dengan ruang diskret. Oleh karena itu MADM digunakan untuk melakukan seleksi dan penilaian terhadap beberapa alternative dari beberapa kriteria dalam jumlah yang terbatas.

Perbedaan antara MADM dan MODM. MADM digunakan untuk menyeleksi alternative terbaik dari sejumlah alternative; sedangkan MODM merancang alternative terbaik.

Tabel 1. Perbedaan MADM dan MODM

\begin{tabular}{l|l|l}
\hline & MADM & MODM \\
\hline $\begin{array}{l}\text { Kriteria } \\
\text { (didefinisikan } \\
\text { oleh) }\end{array}$ & Atribut & Tujuan \\
\hline Tujuan & Implisit & Ekplisit \\
\hline Atribut & Ekplisit & Implisit \\
\hline Alternatif & $\begin{array}{l}\text { Diskret, } \\
\text { dalam jumlah } \\
\text { terbatas }\end{array}$ & $\begin{array}{l}\text { Kontinu, } \\
\text { dalam jumlah } \\
\text { tak terbatas }\end{array}$ \\
\hline Kegunaan & Seleksi & Desain \\
\hline
\end{tabular}

Beberapa fitur umum yang akan digunakan dalam MCDM (Jonko, 2005), yaitu:

a. Alternatif, alternatif adalah objek-objek yang berbeda dan memiliki kesempatan yang sama untuk dipilih oleh pengambil keputusan. 
b. Atribut, atribut sering juga disebut sebagai karakteristik, komponen, atau kriteria keputusan. Kebanyakan kriteria bersifat satu level, namun tidak menutup kemungkinan adanya sub kriteria yang berhubungan.

c. Beberapa kriteria biasanya mempunyai konflik antara satu dengan yang lainnya, misalnya antara kriteria keuntungan (benefit) dan kriteria biaya (cost)

d. Bobot keputusan menunjukkan kepentingan yang relative dari setiap kriteria, $\mathrm{W}=\left(\mathrm{w}_{1}, \mathrm{w}_{2}\right.$, $\left.\mathrm{w}_{3}, \ldots \ldots \ldots \ldots \mathrm{w}_{\mathrm{n}}\right)$. pada MCDM akan dicari bobot kepentingan dari setiap kriteria.

Suatu matrik keputusan $\mathrm{X}$ yang berukuran $\mathrm{m} \mathrm{x} \mathrm{n}$, berisi elemen-elemen $\mathrm{x}_{\mathrm{ij}}$, yang merepresentasikan rating dari alternative $\mathrm{A}_{\mathrm{i}}(\mathrm{i}=1,2,3, \ldots \ldots, \mathrm{m})$ terhadap kriteria $C_{j}(j=1,2,3, \ldots \ldots, n)[2]$.

\section{b. Konsep Dasar Multiple-Attribute Decision Making (MADM)}

Pada dasarnya, proses MADM dilakukan melali 3 tahap, yaitu penyusunan komponenkomponen situasi, analisis, dan sintesis informasi (Rudolphi, 2000), [3]. Pada tahap penyusunan komponen, komponen situasi, akan dibentuk table taksiran yang berisi identifikasi alternatif dan spesifikasi tujuan, kriteria dan attribute. Salah satu cara untuk menspesifikasikan tujuan situasi | $\mathrm{O}_{\mathrm{i}}$, $\mathrm{i}=1, \ldots \mathrm{t} \mid$ adalah dengan cara mendaftar konsekuensikonsekuensi yang mungkin dari alternatif yang telah teridentifikasi $\left|A_{i}, i=1, \ldots . n\right|$. Selain itu juga disusun atribut-atribut yang akan digunakan $\left|\mathrm{a}_{\mathrm{k}}, \mathrm{k}=1, \ldots \mathrm{m}\right|$.

Model Multi-Attrbut Decision Making (MADM) adalah mengevaluasi $\mathrm{N}$ alternatif $A_{i}(i=1,2, \ldots, N)$ terhadap $\mathrm{M}$ atribut atau kriteria $C_{j}(j=1,2, \ldots, M)$, dimana setiap atribut saling tidak bergantung satu dengan yang lainnya. Matriks keputusan setiap alternatif terhadap setiap atribut, $\mathrm{X}$ diberikan sebagai : (Kusumadewi, 2006).

$X=\left[\begin{array}{cccc}x_{11} & x_{12} & \ldots & x_{1 n} \\ x_{21} & x_{22} & & x_{2 n} \\ \vdots & \vdots & & \vdots \\ x_{m 1} & x_{m 2} & \cdots & x_{m n}\end{array}\right]$

Dimana $x_{i j}$ merupakan rating kinerja

alternatif ke-i terhadap atribut ke-j. Nilai bobot yang menunjukkan tingkat kepentingan relatif setiap atribut, diberikan sebagai, $\mathrm{W}$ :

$W=\left\{w_{1}, w_{2}, w_{3}, \ldots w_{n}\right\}$

Rating kinerja (X), dan nilai bobot (W) merupakan nilai utama yang merepresentasikan preferensi absolut dari pengambil keputusan. MADM diakhiri dengan proses perankingan untuk mendapatkan alternatif terbaik yang diperoleh berdasarkan nilai keseluruhan preferensi yang diberikan, [1].

\section{c. Technique for Order Preference by Similarity to Ideal Solution (TOPSIS)}

Metode Technique for Order Preference by Similarity to Ideal Solution (TOPSIS) didasarkan pada konsep dimana alternatif terpilih yang terbaik tidak hanya memiliki jarak terpendek dari solusi ideal positif, namun juga memiliki jarak terpanjang dari solusi ideal negatif (Kusumadewi, 2006). Konsep ini banyak digunakan pada beberapa model MADM untuk menyelesaikan masalah keputusan secara praktis. Hal ini disebabkan konsepnya sederhana dan mudah dipahami, komputasinya efisien, dan memiliki kemampuan untuk mengukur kinerja relatif dari alternatif-alternatif keputusan dalam bentuk matematis yang sederhana.

Secara umum langkah-langkah atau prosedur Metode Technique for Order Preference by Similarity to Ideal Solution (TOPSIS) adalah sebagai berikut:

a) Membuat matriks keputusan yang ternormalisasi;

b) Membuat matriks keputusan yang ternormalisasi terbobot;

c) Menentukan matriks solusi ideal positif dan matriks solusi ideal negatif;

d) Menentukan jarak antara nilai setiap alternatif dengan matriks solusi ideal positif dan matriks solusi ideal negatif;

e) Menentukan nilai preferensi untuk setiap alternatif.

Metode Technique for Order Preference by Similarity to Ideal Solution (TOPSIS) membutuhkan rating kerja setiap alternatif Ai pada setiap kriteria $\mathrm{Cj}$ yang ternormalisasi, yaitu:

$$
\mathrm{r}_{\mathrm{ij}}=\frac{x_{i j}}{\sqrt{\sum_{i=1}^{m} x_{i j}^{2}}}
$$

$\mathrm{i}=1,2, \ldots, \mathrm{m} ;$ dan $\mathrm{j}=1,2, \ldots \ldots \ldots . \mathrm{n}$

Solusi ideal positif $\mathrm{A}^{+}$dan solusi ideal negatif $\mathrm{A}^{-}$ dapat ditentukan berdasarkan rating bobot ternormalisasi $\left(\mathrm{y}_{\mathrm{ij}}\right)$ sebagai :

$$
\begin{gathered}
\mathrm{y}_{\mathrm{ij}}=\mathrm{w}_{\mathrm{i}} \cdot \mathrm{r}_{\mathrm{ij}} \\
\mathrm{i}=1,2, \ldots, \mathrm{m} ; \operatorname{dan} \mathrm{j}=1,2, \ldots, \mathrm{n} \\
\mathrm{A}^{+}=\left(\mathrm{y}_{1}^{+}, \mathrm{y}_{2}^{+}, \ldots, \mathrm{y}_{\mathrm{n}}^{+}\right) \\
\mathrm{A}^{-}=\left(\mathrm{y}_{1}^{-}, \mathrm{y}_{2}^{-}, \ldots, \mathrm{y}_{\mathrm{n}}^{-}\right)
\end{gathered}
$$

dengan

$$
\mathrm{y}_{\mathrm{j}}^{+}=\max \mathrm{y}_{\mathrm{ij}} \text {, jika } \mathrm{j} \text { adalah atribut keuntungan }
$$
(benefit)

min $y_{\mathrm{ij}}$, jika j adalah atribut biaya (cost)

$\mathrm{y}_{\mathrm{j}}^{-}=\max \mathrm{y}_{\mathrm{ij}}$, jika $\mathrm{j}$ adalah atribut keuntungan (benefit)

$\min \mathrm{y}_{\mathrm{ij}}$, jika $\mathrm{j}$ adalah atribut biaya (cost) $\mathrm{j}=1,2, \ldots, \mathrm{n}$

Jarak antara alternatif $A_{i}$ dengan solusi ideal positif dirumuskan sebagai berikut :

$\mathrm{D}_{\mathrm{i}}^{+}=\sqrt{\sum_{i=1}^{n}\left(y_{i}^{+}-y_{i j}\right)^{2}} ; \mathrm{i}=1,2, \ldots, \mathrm{m}$.

Jarak antara alternatif $A_{i}$ dengan solusi ideal negatif dirumuskan sebagai berikut : 
$\mathrm{D}_{\mathrm{i}}^{-}=\sqrt{\sum_{j=1}^{n}\left(y_{i j}-y_{i}^{-}\right)^{2}} ; \mathrm{i}=1,2, \ldots, \mathrm{m}$.

Nilai preferensi untuk setiap alternatif $\left(\mathrm{V}_{\mathrm{i}}\right)$ diberikan sebagai:

$$
\mathrm{V}_{\mathrm{i}}=\frac{D_{i}^{-}}{D_{i}^{-}+D_{i}^{+}} ; \mathrm{i}=1,2, \ldots, \mathrm{m} .
$$

Nilai $\mathrm{V}_{\mathrm{i}}$ yang lebih besar menunjukkan bahwa alternatif $\mathrm{A}_{\mathrm{i}}$ lebih dipilih, [1].

\section{d. Kecerdasan Ganda}

Gardner (2003) berpendapat bahwa terdapat delapan macam kecerdasan yang dimiliki oleh manusia kemudian dikenal sebagai kecerdasan ganda (Multiple Intelligence) atau biasa disingkat dengan MI. Kedelapan jenis kecerdasan tersebut adalah 1).Musical (rhythmic intelligence) 2).Bodily (kinesthetic intelligence), 3).Logical (mathematical intelligence), 4).Visual (spatial intelligence), 5).Verbal (linguistic intelligence), 6).Interpersonal intelligence, 7).Intrapersonal intelligence dan 8).Naturalistic intelligence.

Kecerdasan Ganda merupakan pengembangan dari IQ (Intelligence Quotient/Kecerdasan otak), EQ (Emotional quotient/kecerdasan emotional), dan SQ (spiritual quotient/kecerdasan spiritual). Kecerdasan adalah kemampuan yang dimiliki oleh setiap orang yang digunakan untuk membuat sesuatu yang dapat berguna bagi orang lain atau mencari solusi dalam menghadapai masalah dan dalam menyelesaikan. Sedangkan Howard Gardner mendefinisikan kecerdasan sebagai berikut : Kemampuan untuk memecahkan suatu masalah, Kemampuan untuk menciptakan masalah baru untuk dipecahkan.

Empat teori Gardner yang telah menetapkan syarat khusus dan harus terpenuhi dalam setiap kecerdasan untuk dimasukkan dalam teorinya diantaranya adalah:

1. Setiap kecerdasan dapat dilambangkan

Teori kecerdasan ganda menyatakan bahwa setiap kecerdasan dapat dilambangkan dalam berbagai cara. Seperti dalam ilmu matematika ada lambang, musik ada lambing (not), kinestetik ada lambing atau irama gerak, lambaian tangan, untuk selamat tinggal atau mau tidur dan lain - lain.

2. Setiap Kecerdasan mempunyai riwayat perkembangan

Kecerdasan bukanlah ciri mutlak yang sudah ditetapkan saat lahir atau tidak berubah sepanjang hidup. Artinya tidak seperti IQ yang meyakini bahwa kecerdasan itu mutlak tetap dan sudah ditetapkan saat kelahiran atau tidak berubah, MI (Multiple Intelligences) percaya bahwa kecerdasan itu muncul pada titik tertentu dimasa anak-anak, mempunyai periode yang berpotensi untuk berkembang selama rentang hidup, dan berisikan pola unik yang secara berlahan atau cepat semakin merosot seiring dengan menuanya seseorang. Kecerdasan paling awal muncul adalah Musik lalu Logis - Matematis.

3. Setiap Kecerdasan rawan terhadap cacat akibat kerusakan atau cedera pada wilayah otak tertentu.

Kecerdasan linguistik ada pada belahan otak kiri, sementara musik, spatial dan antarpribaldi) cenderung di belahan otak kanan. Kinestetik jasmani menyangkut kortek motor, ganglia basal, dan serebellum (otak kecil). Lobus frontal mengambil peran penting pada kecerdasan intrapribadi (intrapersonal).

4. Setiap kecerdasan mempunyai keadaan akhir berdasar nilai budaya.

Artinya tidak harus matematis - logig atau Spatial atau Musik atau tergantung budaya masing masing misal ada kemampun naik kuda, melacak jejak dan lain-lain, dalam budaya tertentu itu sangat - sangat penting, [4].

\section{Metode Penelitian}

Tahapan dalam menyelesaikan penelitian ini adalah menggunakan metode waterfall dimana pengerjaan dilakukan dari atas ke bawah secara berurutan. Langkah-langkah yang akan dilakukan dalam penelitian ini, yaitu sebagai berikut :

1.Studi Pustaka adalah teori-teori yang perlu dipahami untuk mendukung kelancaran penelitian ini. Berikut adalah teori-teori pendukung yang dimaksud :

a) Mempelajari tentang Multi Attribute Decision Making (MADM) menggunakan sebuah metode Technique for Order Preference by Similarity to Ideal Solution (TOPSIS).

b) Mempelajari cara kerja metode Technique for Order Preference by Similarity to Ideal Solution (TOPSIS) dan kecerdasan ganda yang dimiliki setiap manusia dengan membuat alat uji tes berdasakan instrument dari delapan kecerdasan yang akan integrasikan dengan jurusan di Sekolah Menengah Atas yaitu IPA, IPS dan Bahasa.

c) Mempelajari algoritma yang akan digunakan dalam sebuah Decision Support System (SPK/DSS) untuk memberikan sebuah keputusan yang berdasarkan Metode Technique for Order Preference by Similarity to Ideal Solution (TOPSIS).

2.Desain dalam membuat sebuah system DSS (decision support system) menggunakan metode Technique for Order Preference by Similarity to Ideal Solution (TOPSIS).

3.Implementasi sistem yang telah di desain dengan diuji coba dan evaluasi sistem. Hal ini dilakukan untuk melihat sejauh mana akurasi sistem yang telah dibuat.

4.Verifikasi untuk mengevaluasi dari hasil implementasi sistem yang telah di tes dan diuji coba.

5.Perbaikan atau maintenance apabila sistem sudah 
6.berjalan dan diujicobakan kepada siswa.

Berikut ini gambaran langkah-langkah dalam pengerjaan penelitian ini

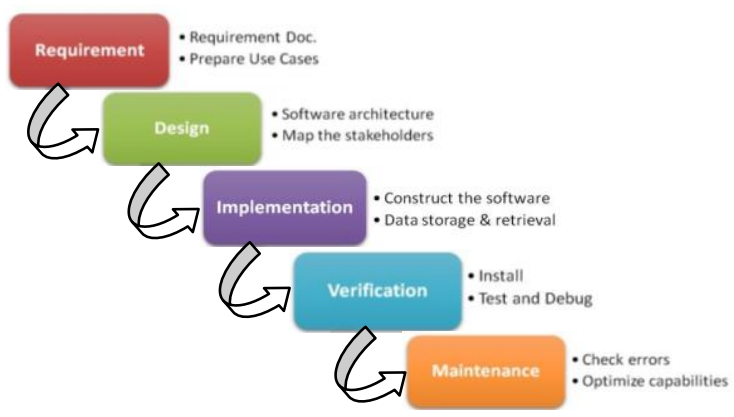

Gambar 1. Model Waterfall

Untuk menjalankan penelitian ini tim pengusul membagi kegiatan dengan beberapa tahap, yaitu:

a) Tahap Persiapan

Dalam tahap persiapan ini tim pengusul melakukan pendekatan kepada sekolah tempat penelitian yaitu di SMA Negeri 1 Gondanglegi Kabupaten Malang, Observasi dan menanyakan tentang proses penjurusan dan variable yang digunakan dalam jurusan yang ada disekolah tersebut.

b) Tahap Pelaksanaan

Pada tahap pelaksanaan ini dibagi dalam beberapa kegiatan, yaitu: 1).Melakukan tes kecerdasan ganda yang dibagikan kepada siswa kelas 1 untuk memilah kecerdasan yang dimiliki oleh siswa. 2).Mengumpulkan nilai raport yang ada kaitannya dengan penjurusan seperti nilai raport matapelajaran matematika, bahasa, ilmu pengetahuan alam dan lain sebagainya.

c) Tahap pengujian Sistem

Pada tahap pelaksanaan ini nilai raport dan hasil uji delapan kecerdasan digabungkan dan dihitung menggunakan metode Technique for Order Preference by Similarity to Ideal Solution (TOPSIS) untuk memperoleh hasil yang direkomendasikan oleh sistem.

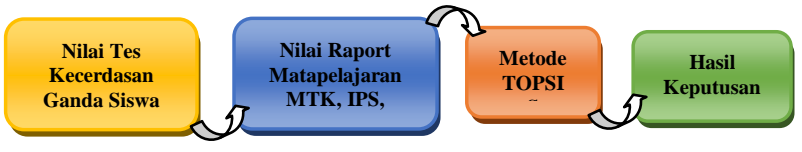

Gambar 2. Teknik Pengumpulan dan Analisi Data.

Tahapan yang dilakukan dalam penelitian meliputi melakukan survey ke SMA (Sekolah Menegah tingkat Atas) Negeri yang ada di Kota dan Kabupaten Malang diantara beberapa pelaksanaan dalam penelitian adalah:

1. Membuat atau menyusun angket/soal tes sebagai alat atau instrunen penelitian.
2. Observasi koordinasi ke SMA Negeri 1 Gondanglegi, MAN 2 Malang dan SMA Negeri 6 Malang, selanjutnya menyebar angket/quisioner awal sebagai instrument penelitian.

3. Angket yang sudah diisi oleh siswa selanjutnya dilakukan analisis menggunakan SPSS untuk uji validitas dari soal yang telah dibuat.

4. Studi Pustaka adalah teori-teori yang perlu dipahami untuk mendukung kelancaran penelitian ini. Berikut adalah teori-teori pendukung yang dimaksud:

a. Mempelajari tentang Multi Attribute Decision Making (MADM) dan Metode Technique for Order Preference by Similarity to Ideal Solution (TOPSIS)

b. Mempelajari cara kerja metode Technique for Order Preference by Similarity to Ideal Solution (TOPSIS) dan Multiple Intelligence yang akan diterapkan untuk menentukan kecerdasan anak.

c. Mempelajari algoritma yang akan digunakan dalam sistem pendukung keputusan (Decision Support System).

5. Desain sistem Multi Attribute Decision Making (MADM) menggunakan Technique for Order Preference by Similarity to Ideal Solution (TOPSIS) sesuai dengan metode yang ada pada MADM.

6. Sebelum uji coba soal terlebih dahulu dilaksanakan uji coba soal tes kecerdasan majemuk. Selanjutnya jika soal sudah valid dan reliabel maka dilakukan uji coba sistem. Uji coba sistem Multi Attribute Decision Making (MADM) menggunakan Technique for Order Preference by Similarity to Ideal Solution (TOPSIS) sesuai dengan metode yang ada pada MADM.

7. Setelah melakukan uji coba soal dan sistem maka dilaksanakan penelitian yang sesungguhnya, dengan jumlah sampel 300 siswa dari 600 siswa.

8. Setelah dilaksanakan penelitian selanjutnya melihat apakah masih ada eror dari hasil yang sudah dilaksanakan. Jika terjadi eror maka akan dillakukan perbaikan sistem dan di uji ulang.

\section{Hasil dan Pembahasan}

Dari seluruh metode yang sudah dilaksanakan maka proses penelitian sudah berjalan sebesar $70 \%$. Uji coba angket dilaksanakan 2 kali, karena soal dalam angket tidak valid pada uji coba pertama. Uji coba validitas dan reliabel soal kecerdasan dilaksanakan di MAN Negeri 6 Malang dan MAN 1 Gondanglegi Malang yang diujikan kepada siswa baru tahun ajaran 2018-2019.

Uji Validitas adalah suatu ukuran yang menunjukkan tingkat-tingkat kevalidan (kesahihan) sesuatu instrumen (Arikunto, 2010:211). Instrumen yang valid adalah instrumen yang dapat 
mengungkapkan variabel yang diteliti secara tepat. Untuk mendapatkan instrumen yang memiliki validitas logis, sebagai langkah awal adalah memecah variabel menjadi subvariabel dan indikator yang kemudian dirumuskan dalam pernyataan. Selanjutnya untuk mendapatkan validitas empiris atau pengalaman maka perlu adanya uji coba instrumen. Apabila data yang didapat dari uji coba ini sudah sesuai dengan seharusnya, itu berarti bahwa instrumen sudah baik. Guna mengetahui ketetapan data ini diperlukan teknik uji validitas (Arikunto, 2010:212). Adapun teknik uji validitas yang dilaksanakan adalah melalui analisis butir soal dengan bantuan komputer program SPSS 22.00 for Windows. Berikut ini table hasil uji coba validitas dari soal kecerdasan.

Berdasarkan tabel maka pengujian reliabilitas instrumen ini diperoleh hasil sebagai berikut:

Tabel 2. Pengujian Reliabilitas instrument penelitian

\begin{tabular}{|c|c|c|}
\hline $\begin{array}{c}\text { Jenis } \\
\text { kecerdasan }\end{array}$ & $\begin{array}{c}\text { Contribusi } \\
\text { Alpha }\end{array}$ & Keterangan \\
\hline $\begin{array}{l}\text { Kecerdasan } \\
\text { Linguistik }\end{array}$ & 0,710 & Reliabel \\
\hline $\begin{array}{l}\text { Kecerdasan } \\
\text { Visual }\end{array}$ & 0,816 & $\begin{array}{l}\text { Sangat } \\
\text { reliabel }\end{array}$ \\
\hline $\begin{array}{l}\text { Kecerdasan } \\
\text { Matematis }\end{array}$ & 0,806 & $\begin{array}{l}\text { Sangat } \\
\text { reliabel }\end{array}$ \\
\hline $\begin{array}{l}\text { Kecerdasan } \\
\text { Kinestetik }\end{array}$ & 0,795 & $\begin{array}{l}\text { Sangat } \\
\text { reliabel }\end{array}$ \\
\hline $\begin{array}{l}\text { Kecerdasan } \\
\text { Musical }\end{array}$ & 0,859 & $\begin{array}{l}\text { Sangat } \\
\text { reliabel }\end{array}$ \\
\hline $\begin{array}{l}\text { Kecerdasan } \\
\text { Interpersonal }\end{array}$ & 0,810 & $\begin{array}{l}\text { Sangat } \\
\text { reliabel }\end{array}$ \\
\hline $\begin{array}{l}\text { Kecerdasan } \\
\text { Intrapersonal }\end{array}$ & 0,806 & $\begin{array}{l}\text { Sangat } \\
\text { reliabel }\end{array}$ \\
\hline $\begin{array}{l}\text { Kecerdasan } \\
\text { Naturalis }\end{array}$ & 0,795 & $\begin{array}{l}\text { Sangat } \\
\text { reliabel }\end{array}$ \\
\hline
\end{tabular}

Berdasarkan hasil uji reliabilitas instrumen yang nampak dalam tabel, maka dapat diketahui bahwa nilai Cronbach Alpha 0,710-0,859 mendekati angka 1, dengan demikian dapat dinyatakan bahwa instrumen yang digunakan reliabel.

Angket yang telah disebar atau diuji validitas dan reabilitas langsung disebar kembali ke siswa SMA Negeri 1 Gondanglegi untuk diuji kemudian menerapkan Metode TOPSIS dengan contoh perhitungan sebagai berikut: Contoh kasus adalah merupakan salah satu siswa dari SMA Negeri 1 Gondanglegi dengan nama siswa Dewi Susislowati.

Tabel 3. Alternatif dan Kriteria

\begin{tabular}{|l|c|c|c|c|c|c|c|c|}
\hline Cost benefit & Cost & Benefit & Benefit & Benefit & Benefit & Benefit & Benefit & Cost \\
\hline Kepentingan & 3 & 3 & 3 & 3 & 3 & 5 & 4 & 2 \\
\hline Alternatif dan Kriteria & C1 & C2 & C3 & C4 & C5 & C5 & C7 & C8 \\
\hline IPA & 85 & 85 & 82 & 88 & 89 & 82 & 1 & 217 \\
\hline IPS & 79 & 84 & 83 & 84 & 81 & 90 & 0.5 & 159 \\
\hline BAHASA & 82 & 79 & 81 & 81 & 78 & 76 & 0.5 & 157 \\
\hline
\end{tabular}

$\underline{\text { Keterangan dari Nilai Kepentingan }}$

1. Sangat Rendah

2. Rendah

3. Cukup

4. Tinggi
5. Sangat Tinggi

Ketrangan dari Kriteria

C1 : Nilai raport Smter 1

C2 : Nilai raport Smter 2

C3 : Nilai raport Smter 3

C4 : Nilai raport Smter 4

C5 : Nilai raport Smter 5

C6 : Nilai Ujian

C7 : Pilihan Siswa

C8 : Nilai Tes Kecerdasan Ganda

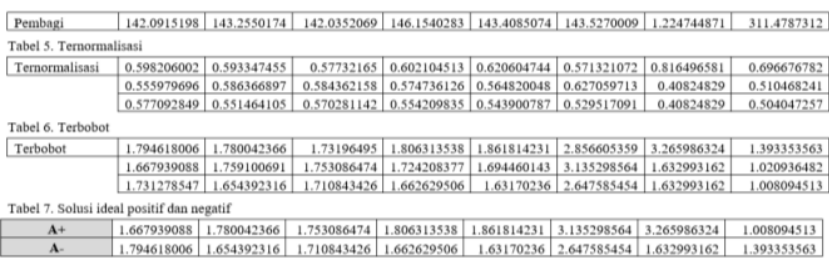

Tabel 8. Nilai_preferensi

\begin{tabular}{|c|c|}
\hline D+ & D- \\
\hline 0.406101 & 0.299718 \\
\hline 0.188022 & 0.418594 \\
\hline 0.308514 & 0.390431 \\
\hline $\mathbf{V}$ & Hasil \\
\hline 0.4246381 & 4 IPA \\
\hline 0.6900481 & 5 IPS \\
\hline 0.5586005 & 3 BAHASA \\
\hline
\end{tabular}

Hasil Terbesar adalah Nilai yang terbesar dari nilai $\mathrm{V}$ yaitu: 0.69004815 (IPS)

\section{Kesimpulan dan Saran}

Technique for Order Preference by Similiarty to Ideal Solution (TOPSIS) dapat menentukan jurusan di SMA (Sekolah Menengah Atas) Negeri 1 Gondanglegi dengan jumlah responden/siswa 230 siswa yang berdasarkan kecerdasan ganda dan dilakukan pengujian instrument di SMA 6 Negeri Malang. Hasil dari penelitian dapat membantu guru BK dalam menetukan kecerdasan yang dimiliki oleh siswa sehingga arahan dalam belajar dapat diketahui namun masa depan anak dalam menempuh studi selanjutnya tidak dapat dipaksa karena keinginan anak berbeda dengan hasil yang diperoleh dari penentuan jurusan.

\section{Daftar Pustaka}

[1] Adi W, Gunawan., 2006. Genius Learning Strategy. Jakarta : Penerbit Gramedia Utama.

[2] Ahsan Moh, Budi P, Harry S.P., 2015. Multiple Intelligence Menentukan Jurusan di SMA Menggunakan Teknik Multi-Attribute Decision Making. Jurnal eeccis UB, Volume 9 tahun 2015.

[3] Arikuto, Suharsimi., 2010.Prosedur Penelitian Suatu Pendekatan Praktek. Jakarta: PT Renika Cipta. 
[4] Ahsan Moh, Romia H.S, Riski Nur I.S., 2015. MultiAttribute Decision Making Untuk Menentukan Multiple Intelligence Anak Menggunakan Metode Weighted Product. JIMP - Jurnal Informatika Merdeka Pasuruan Vol.2 No.2 Agustus 2017 ISSN 2503-1945.

[5] Hasan, I. 2002. Pokok-Pokok Statistik 1 (Statistik Diskriptif). Jakarta: PT.Aksara.

[6] Kusumadewi S, Hartati S, Harjoko A, dan Wardoyo R. 206. Fuzzy Multi-Attributr Decision Making (FUZZY MADM). Yogyakarta: Graha Ilmu.

[7] Lucy, Bunda. 2010. Mendidik Sesuai Minat dan Bakat Anak (Painting Your Children's Future). Jakarta: PT.Tangga Pustak.

[8] Sarwoko, Endi. 2010. Modul Praktiakan Statistik SPSS 22,0 For Windows. Malang Universitas Kanjuruhan Malang. 